\title{
SYNTHESIS OF A NOVEL SERIES OF SCHIFF'S BASES FROM PABA AND PHENYL HYDRAZINE AND EVALUATION OF THEIR ANTIOXIDANT ACTIVITY
}

\author{
Yalamanchili Praharsha*1, Sashmitha Samuel.B ${ }^{2}$ \\ *IAssistant Professor, Department of Pharmaceutical Chemistry, MLRIP, Dundigal, T.S \\ ${ }^{2}$ Associate Professor, Department of Pharmaceutical Chemistry, MLRIP, Dundigal, T.S
}

*Corresponding Author: Yalamanchili Praharsha

Article DOI: https://doi.org/10.36713/epra8509

DOI No: 10.36713/epra8509

\begin{abstract}
Over the past decade, the synthesis of Schiff's bases has become one of the main areas of interest in synthetic chemistry. These compounds have gained much attention, owing to their potential role as anti-inflammatory, anthelmintic, analgesic, antibacterial and antifungal agents. Thus, in view of the significance and diverse therapeutic activities of Schiff's bases we have aimed at a simple and efficient procedure for their synthesis by the reaction of various aldehydes with $P A B A$ and phenyl hydrazine and also evaluation of their antibacterial activities. We have been successful in synthesizing various Schiff's bases and also these compounds have been proved to have effective anti-oxidant activity.

KEYWORDS: Schiff's bases, PABA, Phenyl hydrazine, Aldehydes, Dioxan, Hydrogen peroxide, scavenging activity
\end{abstract}

\section{INTRODUCTION}

Schiff's bases are one of the important classes of synthetic compounds that have gained much attention due to their wide scope of therapeutic activity. These are efficient anti-inflammatory, analgesic, antibacterial and antifungal agents. Hence, we aimed at the synthesis of a novel series of Schiff's bases by the reaction of PABA and Phenyl hydrazine with various aldehydes. We were also successful in evaluating the in vitro antioxidant properties of the synthesized Schiff's bases.

\section{MATERIALS AND METHODS}

All chemicals used in this work were of laboratory grade procured from Hi-Media, E-Merck, and Loba chemicals etc. The percentage yield was based upon the products obtained after purification and recrystallization. The melting points of the compounds were determined in one-end open capillary tubes and are uncorrected. Porous silica gel plates activated at $110^{\circ} \mathrm{C}$ for $30 \mathrm{~min}$. were used for thin layer chromatography (TLC) and were developed with iodine vapours. I.R spectra were recorded on Perkin Elmer Model 283B using potassium bromide $(\mathrm{KBr})$ pellet and the wave numbers were given in $\mathrm{cm}^{-1}$.

\section{METHODOLOGY}

Two schemes were employed for the synthesis of Schiff's bases. 


\section{EPRA International Journal of Research and Development (IJRD)}

Scheme-1: The following scheme was employed for the synthesis of Schiff bases 1(a-d)<smiles>Nc1ccc(C(=O)O)cc1</smiles><smiles>[R]c1ccc(C=O)cc1</smiles>

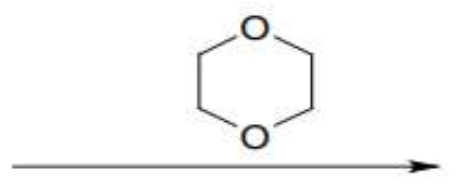<smiles>[R]c1ccc(/C=N/c2ccc(C(=O)O)cc2)cc1</smiles>

$0.1 \mathrm{M}$ Aldehydes had been coupled with $0.1 \mathrm{M}$ of PABA using 1, 4-Dioxan as solvent and was refluxed on heating mantle for an hour. After refluxing; the excess of the solvent was removed. The solid mass that separated out was filtered and recrystallized from $95 \%$ methanol. The whole process of reaction was monitored by TLC method.

Scheme-2: The following scheme was employed for the synthesis of Schiff bases 2(a-d)<smiles>NNc1ccccc1</smiles><smiles>[R]c1ccc(C=O)cc1</smiles>

0.1M Phenyl hydrazine had been coupled with $0.1 \mathrm{M}$ of Aldehydes using 1, 4-Dioxan as solvent and was refluxed on heating mantle for an hour. After refluxing, the excess of the solvent was removed. The solid mass that separated out was filtered and recrystallized from $95 \%$ methanol. The whole process of reaction was monitored by TLC method.

\begin{abstract}
ANTI OXIDANT ACTIVITY
A solution of hydrogen peroxide $(40 \mathrm{mM})$ was prepared in phosphate buffer $(\mathrm{pH}$ 7.4). Different concentrations $(250,500,750$ and $1000 \mu \mathrm{g} / \mathrm{mL})$ of the synthesized compounds were added to hydrogen peroxide solution $(0.6 \mathrm{~mL}, 40 \mathrm{mM})$. Absorbance of hydrogen peroxide at $230 \mathrm{~nm}$ was determined after 10 minutes against a blank solution containing phosphate buffer without hydrogen peroxide. Ascorbic acid was used as the positive control. The ability of the compounds to scavenge the $\mathrm{H}_{2} \mathrm{O}_{2}$ was calculated using the following equation:
\end{abstract}

$\mathrm{H}_{2} \mathrm{O}_{2}$ percentage scavenging activity $=[(\mathrm{A} 0-\mathrm{A} 1) / \mathrm{A} 0] \times 100$

where: $\mathrm{A}_{0}=$ Absorbance of control, $\mathrm{A}_{1}=$ Absorbance of sample.

\section{RESULTS}

Table-1: Chemical data of synthesized compounds

\begin{tabular}{|l|c|c|c|}
\hline S.No. & Compound & Mol.Formula & \% Yield \\
\hline 1 & $1 \mathrm{a}$ & $\mathrm{C}_{14} \mathrm{H}_{11} \mathrm{NO}_{2}$ & 80.2 \\
\hline 2 & $1 \mathrm{~b}$ & $\mathrm{C}_{15} \mathrm{H}_{13} \mathrm{NO}_{2}$ & 84 \\
\hline 3 & $1 \mathrm{c}$ & $\mathrm{C}_{15} \mathrm{H}_{11} \mathrm{NO}_{3}$ & 89.7 \\
\hline 4 & $2 \mathrm{a}$ & $\mathrm{C}_{13} \mathrm{H}_{11} \mathrm{~N}_{2}$ & 85.5 \\
\hline 5 & $2 \mathrm{~b}$ & $\mathrm{C}_{14} \mathrm{H}_{13} \mathrm{~N}_{2}$ & 88.3 \\
\hline 6 & $2 \mathrm{c}$ & $\mathrm{C}_{13} \mathrm{H}_{11} \mathrm{~N}_{2} \mathrm{O}$ & 90.4 \\
\hline
\end{tabular}




\section{EPRA International Journal of Research and Development (IJRD)}

Volume: 6 | Issue: 9 | September 2021

- Peer Reviewed Journal

Table-2: Results of anti-oxidant activity of synthesized compounds

\begin{tabular}{|c|c|c|c|c|c|}
\hline \multirow{2}{*}{ S.No. } & \multirow{2}{*}{ Compound } & \multicolumn{4}{|c|}{ \% Inhibition } \\
\cline { 3 - 6 } & & $\mathbf{2 5 0}(\boldsymbol{\mu} \mathbf{g} / \mathbf{m l})$ & $\mathbf{5 0 0}(\boldsymbol{\mu g} / \mathbf{m l})$ & $\mathbf{7 5 0}(\boldsymbol{\mu g} / \mathbf{m l})$ & $\mathbf{1 0 0 0}(\boldsymbol{\mu g} / \mathbf{m l})$ \\
\hline 1 & 1a & 38.8 & 44.4 & 52.2 & 63 \\
\hline 2 & 1b & 33.3 & 38.8 & 42.6 & 55.5 \\
\hline 3 & 1c & 53.3 & 55.5 & 58 & 65.5 \\
\hline 4 & 2a & 55 & 61.1 & 67.4 & 72.4 \\
\hline 5 & 2b & 46.6 & 53.3 & 61 & 69.5 \\
\hline 6 & 2c & 60 & 64.4 & 72.1 & 78.4 \\
\hline 7 & Ascorbic acid & 68.8 & 75 & 84.2 & 95.2 \\
\hline
\end{tabular}

Figure-1: Anti-oxidant activity of synthesized compounds

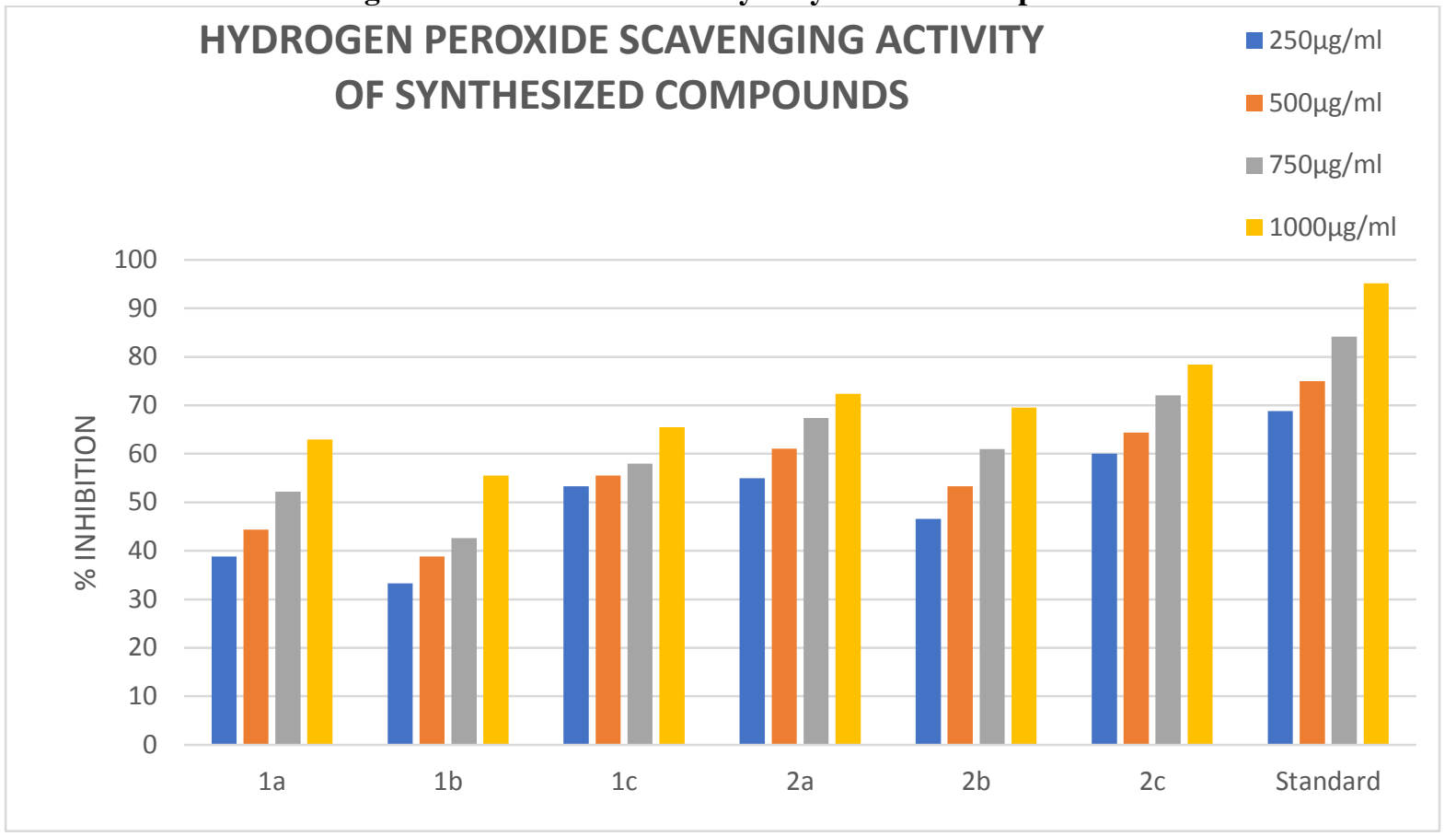

\section{CONCLUSION}

The Schiff's bases which have been synthesized were screened for anti-oxidant activity against by hydrogen peroxide scavenging method. The percentage inhibition was taken as a parameter of anti-oxidant activity. The percentage inhibition of the test compounds is compared to that of Ascorbic acid. Almost all the compounds showed satisfactory activity, however compounds $2 \mathrm{a}$ and $2 \mathrm{c}$ showed maximum activity.

\section{REFERENCES}

1. Pandeya SN, Sriram D. Synthesis and screening for antibacterial activity of Schiff's and Mannich bases of Isatin and its derivatives. Acta Pharm Turc 1998; 40:33-38

2. Pandeya SN, Sriram D, Nath G, De Clercq E. Synthesis, characterization and evaluation of antibacterial, antifungal and anti-HIV activity of Schiff's and Mannich bases of isatin with N-[6-
Chlorobenz thiazole-2-yl]thio semicarbazide. Indian J Pharm Sci 1999; 61:358-61

3. Rajaram Prakash Chinnasamy, Synthesis, characterization and analgesic activity of novel Schiff bases of isatin derivatives, JAPTR, 2010, Vol.1, Issue 3,342-347.

4. Lamani.K.S.S, Synthesis, characterization and antimicrobial properties of Schiff bases derived from condensation of 8-formyl-7-hydroxy-4methyl coumarin and substituted triazole derivatives, E-journal of chemistry, 2009, 6, S239-246.

5. M.S. Alam, D.U. Lee, Synthesis, molecular structure and antioxidant activity of (E)-4[Benzylideneamino]-1,5-dimethyl-2-phenyl-1Hpyrazol-3(2H)-one, a Schiff bases ligand of 4aminoantipyrine, J. Chem. Crystallogr., 42 (2012), pp. 93-102 